\title{
REVIEWS
}

Reviews of books, reports, papers and other publications should be sent to J. Walter Giles, Book Review Co-ordinator, Department of Lands and Forests, Pembroke, Ont. Please mention that you saw the review in the Forestry Chronicle when purchasing books from publishers.

\section{CURRENT PUBLICATIONS}

\section{Management}

Anderson, R. L. and D. D. Skilling. July, 1955. Oak wilt damage-a survey in Central Wisconsin. Station Paper 33, Lake States Forest Experiment Station, St. Paul, Minn. 11 pp.

Bedell, G. H. D. and A. B. Berry. 1955. A method of determining approximate merchantable volumes. Tech. Note 14, Forestry Branch, Department of Northern Affairs and National Resources, Ottawa. 4 pp.

Brown, W. G. E. February, 1956. Roads and land. Reprint Timber of Canada, $7 \mathrm{pp}$.

Camp, H. W. January, 1956. Economics research needs related to wild land management and development in the mountain states. Research Paper 38, Inter-Mountain Forest and Range Experiment station, Ogden, Utah. 27 pp.

Canada, Forestry Branch, Forest Research Division. 1955. Forest fire losses in Canada, 1954. Ottawa. 14 pp. plus tables.

Carl, C. M., Mossan, J. C. and H. E. Young. 1955. White pine topwood volume tables, Tech. Note 36, University of Maine, Forestry Department, Orono, Maine. 4 pp.

Copeland, Otis L. Jr. and C. D. Leatheart. 1955. Preliminary report on soilrootlet relationships to pole blight of western white pine. Research Note 22, Inter-Mountain Forest and Range Experiment Station, Ogden, Utah. $6 \mathrm{pp}$.

Curtis, James D. 1955. Forest management research by the Inter-Mountain and Northern Rocky Mountain Stations, a bibliography 1912 through 1954. Miscellaneous Publication No. 6, Inter-Mountain Forest and Range Experiment Station, Ogden, Utah. 42 pp.

Dimuk, E. J. 1956. Selection thinning in young-growth Douglas fir. A six-year progress report. Research Note 127, Pacific North-West Forest and Range Experiment Station, Portland, Oregon. 6 pp.

Fenton, R. H. and F. H. Berry. 1956. Heart rot of Virginia pine in Maryland. Forest Research Note 56, North-Eastern Forest Experiment Station, Upper Darby, Pa. 4 pp.

Driscoe, W. H. 1956. A study of the effects of the application of marking rules upon stand conditions in a spruce-fir forest in Eastern Maine. Tech. Note 40, University of Maine Forestry Department, Orono, Maine. 2 pp. 
Grosenbaugh, L. R. 1955. Better diagnosis and prescription in southern forest management. Occasional Paper 145, Southern Experiment Station. 27 pp.

Herrington, R. B. 1955. Northern Rocky Mountain pole production in 1954. Research Note 24, Inter-Mountain Forest and Range Experiment Station, Ogden, Utah. 4 pp.

Johnson, Floyd A. 1956. Use of a bark thickness-tree diameter relationship for estimating past diameters of Ponderosa pine trees. Research Note 126, Pacific North-West Forest and Range Experiment Station, Portland, Oregon. 3 pp.

Jorgensen, E. 1956. Fomes root rot of pines. Forest Pathology Laboratory, Southern Research Station, Maple, Ontario. 3 pp.

Little, S. and H. A. Somes. 1956. Thinning young oak stands on poor sites in Southern New Jersey does not pay. Forest Research Note 58, NorthEastern Forest Experiment Station, Upper Darby, Pa. 4 pp.

MacAndrews, F. D. 1955. Average height weighted by volume in air photo interpretation. Tech. Note 17, Forestry Branch, Ottawa. 11 pp.

Matson, E. E. 1955. Ponderosa pine lumber recovery in Lakeview, Oregon Area. Research Note 124, Pacific North-West Forest and Range Experiment Station, Portland, Oregon. 12 pp.

McComb, David. 1955. Relationship between trap tree felling dates and subsequent Engelmann spruce beetle attack. Research Note 23, Inter-Mountain Forest and Range Experiment Station, Ogden, Utah. 5 pp.

Whitten, R. R. 1956. Protecting against Dutch elm disease. Miscellaneous Release 10, Central States Forest Experiment Station, Columbus, Ohio. 14 pp.

\section{SILVICULTURE}

Curtis, J. D. 1955. Effects of origin and storage method on the germinative capacity of Ponderosa pine seed. Research Note 26, Inter-Mountain Forest and Range Experiment Station, Ogden, Utah. 5 pp.

Finnis, J. M. 1955. The use of tetramine in the direct seeding of Douglas fir in coastal British Columbia. Research Note 31, B.C. Forest Service, Victoria, B.C. 22 pp.

Fraser, J. W. and J. L. Farrar. 1955. Effect of watering, shading, seed-bed medium, and depth of sowing on red pine germination: Tech. Note 15, Forest Research Division, Forestry Branch, Ottawa. 3 pp.

Heinselman, M. L. and Zasada, Z. A. 1955. A review of literature relating to quaking aspen sites. Station Paper 32, Lake States Forest Experiment Station, St. Paul, Minn. 61 pp. 
Horton, K. W. 1955. Early developments in a sub-alpine lodgepole pine stand of fire origin. Tech. Note 16, Forest Research Division, Forestry Branch, Ottawa. $6 \mathrm{pp}$.

Logan, A. T. 1955. An integrating light meter for ecological research. Tech. Note 13, Forest Research Division, Forestry Branch, Ottawa. 4 pp.

Rushmore, F. M. 1956. Beech root sprouts can be damaged by sodium arsenite treatment of parent tree. Forest Research Note 57, North-Eastern Forest Experiment Station, Upper Darby, Pa. 4 pp.

Roof, R. H. and C. M. Berntsen. 1956. Chemical basal treatment to control red alder. Research Note 128, Pacific North-West Forest and Range Experiment Station, Portland, Oregon. $6 \mathrm{pp}$.

\section{UTILIZATION}

Andrews, G. W. June 1955. Sawing wood with circular head saws. Reprint from Forest Products Journal. $7 \mathrm{pp}$.

Bell, G. E. and E. Brooks. Cord-cubic volume Relationship of slab wood and edgings. Reprint from Timber of Canada, November 1954, 3 pp.

Bramhall, G. and W. M. Conners. 1955. Vapor pressures in western hemlock heartwood during boiling under vacuum in creosote. Reprint Forest Products Journal, August 5 pp.

Clermont, L. P. Fractionation and identification of the hemicellulose components of black spruce. Pulp and Paper Magazine. October 1955, 8 pp.

Eades, H. W. 1956. Sap stain and mould prevention on British Columbia softwoods. Bulletin 116, Forest Products Laboratories, Forestry Branch, Ottawa. 40 pp.

Feihl, O. Rotary cutting of curly yellow birch. Reprint Canadian Woodworker. May and June, 1955, 7 pp.

Matson, E. E. 1956. Lumber grades from old-growth Douglas fir sawmill logs. Research Note 125, Pacific North-West Forest and Range Experiment Station, Portland, Oregon. 6 pp.

McBride, C. F. Losses incurred in drying and dressing lumber in the Southern Interior of British Columbia. Reprint Forest Products Journal. June 1955, $4 \mathrm{pp}$.

McIntosh, D. C. Shrinkage of red oak and beech. Reprint Forest Products Journal. October 1955. 5 pp. 